\title{
Analysis of the Implementation of Annual Tax Reporting Policy among Personal Tax Payer in Indonesia
}

\author{
Dwikora Harjo ${ }^{1}$, Fauzilah Salleh ${ }^{2}$ \\ ${ }^{1}$ Institut Ilmu Sosial dan Manajemen STIAMI, Indonesia \\ ${ }^{2}$ Universiti Sultan Zainal Abidin, Malaysia \\ Correspondent: dwikora.harjo@stiami.ac.id¹ ${ }^{1}$.
}

$\begin{array}{ll}\text { Received } & \text { : August 26, } 2021 \\ \text { Accepted } & \text { : January 15, } 2022 \\ \text { Published } & \text { : January 31, } 2022\end{array}$

Citation: Harjo, D., Salleh, F. (2022). Analysis of the Implementation of Annual Tax Reporting Policy among Personal Tax Payer in Indonesia. Ilomata International Journal of Tax and Accounting, 3(1), 91-102. https://doi.org/10.52728/ijtc.v4i1.429

\begin{abstract}
Individual taxpayers awareness and compliance are predicted to be below expectations in numerous Indonesian regions, as evidenced by the yearly tax reporting (SPT), which is still below the expected aim. The number of taxpayers who submit the SPT is one indicator of compliance; the higher the number of taxpayers who report the SPT, the higher the level of compliance. The goal of this study is to look into how the Cileungsi Pratama Tax Service Office in West Java, Indonesia, implements annual tax reporting for personal taxpayers. The authors apply Van Meter Van Horn's Policy Implementation Theory to six test variables: standards and policy objectives, resources, interorganizational linkages, implementing agent characteristics, social, economic, and political situations, and implementer disposition. The qualitative descriptive approach was adopted in this study. Observation, documentation, and interviews were utilised to collect data, which was then analysed through data reduction, data display, and drawing conclusions. The study's findings demonstrate that, from 2018 to 2020 , individual taxpayers' yearly tax reporting at the Cileungsi Tax Office complied with applicable rules and regulations, but that it fell short of the aim.
\end{abstract}

Keywords: Annual Tax Report, Implementation, Individual Taxpayer

\section{INTRODUCTION}

In the structure of the Indonesian State Revenue and Expenditure Budget, from year to year taxes provide the largest its role in raising funds from the public to the state where the funds collected from the community are used to meet the needs of the state in the welfare of the people (Setiowati et al., 2020). In collecting public funds through this tax, of course, it is necessary to have public awareness, concern and compliance in carrying out their tax obligations (Kumala \& Junaidi, 2019). One form of public compliance in fulfilling their tax obligations is to register as a taxpayer, pay taxes correctly and on time and report a annual tax return (Surat Pemberitahuan) in accordance with the applicable tax provisions (Perdana \& Dwirandra, 2020). 
According to data from the Ministry of Finance's government performance report, the taxing sector made the highest revenue contribution to the 2019 APBN, accounting for 86.5 percent of total income (Direktorat Jenderal Pajak, 2013). The remaining money came from Non-Tax State Revenue and Grants. Its contribution to state revenue is becoming increasingly important due to the fact that taxes are the foundation of state finance. The amount of net tax revenue realised in comparison to the tax revenue target is referred to as realised tax revenue (Direktorat Jenderal Pajak, 2020).

The Directorate General of Taxes undertakes a variety of initiatives to ensure that the tax revenue target is met each year. These initiatives include tax regulatory reform. Not only does tax reform seek to boost public revenue in the form of taxes, but it also seeks to improve taxpayer understanding and compliance with the law (Ciptaningsih, 2013). The online tax reporting by taxpayers represents the most significant effort on the part of the Directorate General of Taxes in the implementation of tax reform (Melando \& Waluyo, 2013). The online service system (tax digitalization administration) aims to improve services to taxpayers so that it is expected to increase taxpayer awareness and compliance in carrying out their tax obligations. The current tax digitalization administrations are e-registration, e-invoicing, e-filing, e-form, and e-billing (Latofah \& Harjo, 2020).

It is suspected that in several regions of Indonesia, taxpayers' level of awareness and compliance with tax obligations is still below the level expected by the government (Rusli, 2019; $\underline{\text { Sinuhaji, }}$ 2019). One indicator of this is the fact that there are still taxpayers who do not fulfil their obligations, such as filing the Annual Tax Return (SPT), which is a report on the annual tax obligations of taxpayers (Ernita \& Sudjiman, 2021). This SPT reporting serves as an indicator of the level of taxpayer compliance; the more the number of SPTs submitted by a taxpayer, the higher the level of taxpayer compliance is considered to be ( $\underline{\text { Adi, 2020 }}$; Rahmadani \& Munawaroh, 2017).

One of the areas in Indonesia that experiences ups and downs in receiving SPT reporting is the Cileungsi Pratama Tax Service Office, Bogor Regency, West Java Province, Indonesia. This area was chosen to be used as a research location in the writing of this scientific paper on the grounds that the reporting fluctuations are quite high and the data obtained is as expected. To find out an overview of this, the following table shows the target and realization of SPT receipts from taxpayers in the working area of the Cileungsi Pratama Tax Service Office from 2018 -2020:

Table 1 Target and Realization of Taxpayer Annual Tax Reporting at the Cileungsi Pratama Tax Service Office, Bogor Regency 
Analysis of the Implementation of Annual Tax Reporting Policy among Personal Tax Payer in Indonesia

Harjo and Salleh

\begin{tabular}{lccc}
\hline \multicolumn{1}{c}{ Description } & 2018 & 2019 & 2020 \\
\hline Target & 15,58 juta & 18 juta & 19 juta \\
\hline $\begin{array}{l}\text { Realization of WP } \\
\text { Reporting }\end{array}$ & 11,19 juta & 12,19 juta & 10,9 juta \\
\hline Corporate Tax Payer & 854.000 & 961.666 & 657.000 \\
\hline Employee Personal TP & 993.754 & 2.29 juta & 1.2 juta \\
\hline $\begin{array}{l}\text { Non Employee } \\
\text { Personal TP }\end{array}$ & 9.35 juta & 10.11 juta & 9.1 juta \\
\hline
\end{tabular}

Source: PDI KPP Pratama Cileungsi Section, 2021

From the table above, it is found a phenomenon that occurs that there are still many taxpayers who have not reported through the SPT every year, especially in the area of the Cileungsi Pratama Tax Service Office, Bogor Regency where in 2019-2020 SPT reporting was disrupted, one of the causes was the impact of the pandemic. covid-19 where the reporting is no longer through face-to-face but through e-filling and e-spt. Therefore, this makes a lot of taxpayers still do not know and understand the mechanism for reporting the SPT, so that the reporting has decreased from the previous year.

The research objectives to be achieved by the author in writing this scientific work are as follows:

1. To analyze how the Implementation of the Annual Tax Return Reporting Policy for Individual Taxpayers at the Cileungsi Pratama Tax Service Office.

2. To analyze what obstacles are faced in the Implementation of the Policy for Reporting Annual Tax Returns for Individual Taxpayers at the Cileungsi Pratama Tax Service Office.

3. To analyze what efforts are being made in overcoming the obstacles of the Implementation of the Reporting Policy for Annual Tax Returns for Individual Taxpayers at the Cileungsi Pratama Tax Service Office.

Annual Tax Reporting by both Individual Taxpayers and Corporate Taxpayers is a manifestation of the implementation of public policies issued by the Government with the aim of knowing that the implementation of tax collection has been carried out well in an area (Norzhela et al., 2019; Widiastuti, 2017). Public policy itself according to William Dunn is an activity that is interrelated and created by government stakeholders from all aspects as a whole (Pasolong, 2019).

The definition of tax is a people's contribution to the State treasury based on the law (which can be enforced) by not receiving reciprocal services (counter performance), which can be directly shown and which is used to pay general expenses (Hidayat \& Afiyanti, 2019). There are five important elements in taxation, namely, first, there is a contribution from the community to the state, secondly, tax collection must be based on tax laws and regulations, thirdly, in its implementation, the tax regulator can impose tax collection on the community, the fourth, community does not get a direct counter achievement, and fifth, the results of tax revenues will be used to finance state expenditures with the aim of improving people's welfare ( $\underline{\text { Harjo, 2019) }}$. 


\section{Analysis of the Implementation of Annual Tax Reporting Policy among Personal Tax Payer in Indonesia}

Harjo and Salleh

The definition of a tax return is a letter used by a taxpayer to report tax calculations and/or payments, tax objects and/or non-tax objects, and/or assets and liabilities in accordance with the provisions of tax laws and regulations (Diana \& Setiawati, 2017).

Annual Tax Report SPT) is a basic obligation for both Individual Taxpayers and Corporate Taxpayers where this report will summarize all activities related to Taxpayer's taxation during the current tax year. This annual report has the following functions (Rahman et al., 2015):

1) Income Tax Tax Payer

The function of the Annual Tax Report (SPT) for Income Taxpayers is as a suggestion to report and account for the calculation of the actual amount of tax owed and to report on:

a. Payment of tax obligations in the current tax year or part thereof.

b. Income which is a Tax Object or is not a Tax Object.

c. Assets \& liabilities.

d. Deposits from withholding/collectors for withholding or collecting taxes in the current year

2) Taxable Entrepreneur

For taxable entrepreneurs, the function of the SPT is a reporting forum for calculating VAT and Luxury Goods Sales Tax payable, including :

a. Crediting input tax and output tax;

b. Periodically pay or settle taxes by Taxpayer

3) For Tax Withholder or Collector

SPT functions as a means to report and account for taxes withheld or collected and deposited.

Electronic filling (e-Filing) is one way of submitting Annual SPT which is carried out online in real time providing Application Service Provider (ASP) services (Rusli, 2019). Companies providing application services provide facilities and infrastructure for taxpayers who wish to submit their tax returns electronically (Batrancea et al., 2019). Apart from being the party that provides the means for submitting electronic tax returns, ASP also functions as a mediating institution or intermediary that connects taxpayers with tax officials (Wulandari, 2021). In addition, ASP can also provide tax information needed by taxpayers through the website that has been provided (Supriatiningsih \& Jamil, 2021). Meanwhile, the definition of Electronic Tax Return (e-SPT) according to Chairil Anwar Pohan is "Taxpayer SPT data in electronic form made by taxpayers using the e-SPT application that has been provided by the Directorate General of Taxes" (Pohan, 2017)

Policy implementation is an activity to carry out policies, fulfill promises as stated in policy documents (to fulfill), to produce outputs as stated in policy objectives, and to complete the mission that must be realized as contained in the policy objectives (Handoyo, 2012).

Policy implementation according to Van Metter and Van Horn is an action taken by the government and the private sector either individually or in groups intended to achieve the goals of public policy through activities involving various stakeholders. Policy implementation is a very complex process because it not only involves various actors or organizations, but also 
because the implementation process is influenced by various variables, both individual variables and organizational variables that interact with each other. Van Meter and Van Horn explain that there are 6 (six) variables that affect implementation performance ( $\underline{\text { Subarsono, 2019)}}$, namely:

1. Policy standards and objectives

Standards and policy objectives must be clear and measurable, so as not to cause implementation which can lead to conflicts between implementation agents.

2. Resource

Policies need to be supported by resources, both human and non-human resources.

3. Relationships between organizations

The existence of cooperation with related institutions in carrying out a policy will influence and determine the success of the policy or program being implemented.

4. Characteristics of implementing agents

It includes the bureaucratic structure, norms and patterns of relationships that occur in the bureaucracy, all of which will affect the implementation of a program.

5. Social, political and economic conditions

This variable consists of several aspects originating from conditions in the surrounding environment that have the potential to succeed in implementing the policies implemented.

6. Implementor's disposition

The disposition of this implementor includes three important things, namely:

a. the willingness and speed of the implementer in responding to the current policy will affect the success of the policy itself;

b. understanding of the policy also determines the success of the policies implemented

c. fast intervals about the disposition of the implementor, affecting the accuracy and success of a policy

Six variables are significant factors and influence each other and must run accumulatively well so that the performance of this implementation can be fulfilled properly.

Richard Elmore, Michael Lipsky and Benny Hjern, David Porter also produced an implementation model based on the type of public policy that encourages people to do their own policy implementation or still involves government officials but only at a low level.

Several previous studies that are similar to this research include Anda Puspitarini whose research entitled Implementation of the E-Filing system of the Annual PPH Individual Personal Tax Return at the KPP Pratama Surabaya Pabena Cantikan revealed that the implementation of eFiling at the KPP Pratama Surabaya Pabean Cantikan was not effective enough, the implementation of e-Filing was not effective enough. -Filing has also not gone well and the expected intensity has not been maximized due to technical and non-technical constraints. Another factor is that many taxpayers do not know and know the e-filing procedure. The application of e-Filing for the Annual Personal Income Tax Return will be maximized if the KPP Pratama Surabaya Pabean Cantikan provides repairs and improvements to services and facilities to taxpayers (Puspitarini, 2016).

Janika and friends also conducted research on the implementation of electronic SPT reporting in the Bintan area in 2019 with the title Analysis of Tax Policy Implementation Regarding Annual 
Electronic Notification Letters (e-SPT) at the Bintan Pratama Tax Service Office with research results in the process of implementing tax policies Regarding the annual electronic notification letter (e-SPT) at the Bintan Pratama Tax Service Office, it has been running as expected, but researchers find that there are still taxpayers who do not understand the procedure for filling out this electronic notification letter (Janika et al., 2019).

Khalishaheti and Aldilla Gadis in 2017 also researched electronic SPT reporting in Klaten Regency with the title Electronic Annual Tax Return (SPT) Reporting Implementation (Study on E-Filing Programs at the Klaten Pratama Tax Service Office) where the results of their research show that implementation e-filing at the Klaten Pratama Tax Service Office has been running well, as evidenced by the increase in individual taxpayers using e-filing and the preparation steps taken before implementation (Khalishaheti, 2017).

Herawati, Tabroni and Lusiana conducted research on the Effectiveness of Tax Regulations, Dissemination of Taxpayer Understanding and Compliance Strategies in Implementing their Tax Obligations in 2018, from the results of their research they suggested that in order to increase state revenue from taxes, the government should be active in making people aware of their obedience in paying tax. They also argue that the importance of socialization of taxation by KPP to taxpayers through various media. Socialization is carried out not only face-to-face, but also through mass media according to current conditions. The output of this research is the formalization of appropriate socialization standards for KPP in order to increase awareness of taxpayers so that tax revenues automatically increase (Herawati et al., 2018).

From some of the previous studies above, it can be concluded that the implementation of reporting annual tax returns for individual taxpayers has a role, and plays an important role in terms of state revenue receipts. The similarity between several previous studies and this research is that they both examine the implementation of reporting individual taxpayers' annual tax returns in an effort to increase taxpayer compliance. What distinguishes this research is the location of the research carried out at the Cileungsi Pratama Tax Service Office and the year of research.

\section{METHOD}

A descriptive qualitative research approach is used to analyze the problems in this study because the authors want to explore in detail and intensively the policies of the modern tax administration system in an effort to improve taxpayer compliance. In addition, another reason the author chooses a qualitative approach is the study of the literature in this study and the pattern of inductive research thinking. This research is not to test the truth of a theory, but to draw conclusions about what happened.

The type of research used in this research is descriptive research which describes and explains in detail the phenomena or problems that exist in the status of human groups, objects, conditions and systems of thought or events in the present. This type of research seeks to explain certain social phenomena. 


\section{Analysis of the Implementation of Annual Tax Reporting Policy among Personal Tax Payer in Indonesia}

Harjo and Salleh

The data collection techniques used were conducting observations, conducting interviews with several informants and documenting some data that were considered important and relevant to this research. This technique is in accordance with what was stated by Sugiyono that "Data Collection Methods are the methods used by researchers to collect data."

Data analysis technique is an activity that begins with collecting data, then choosing the validity of the data that has been collected, choosing a particular coding with the aim of being effective in conducting research and drawing a decision to do research (Moleong, 2018). In carrying out data analysis techniques, the authors use the techniques proposed by Miles \& Huberman, namely through the stages of data reduction, displaying data and drawing conclusions (Sugiyono, 2019).

The data reduction stage is sorting and selecting the collected data with the aim that the author will choose valid and relevant data to the research to be carried out, so not all the collected data will be used as research data. The next stage is to display the data in this case the author uses verbatim coding to facilitate data analysis and the last stage is to draw conclusions based on the analysis carried out.

In conducting interviews, the writer chose several informants with the criteria that the informants knew and understood about the problems to be analyzed, also the informants were needed to explore the information that became the basis and the theoretical design that was built. In determining informants in qualitative research, it is possible to use three methods, namely the purposive procedure (deliberate), the quota procedure and the snowball procedure. Purposive sampling is the author's choice in selecting informants. The selected informants represent 1 person from the policy maker, 5 taxpayers and 1 person from academics.

This research was conducted by focusing on the implementation of the reporting policy of the Annual Tax Return of Individual Taxpayers at the Cileungsi Pratama Tax Service Office, West Java Province. The author uses the theory of Van Meter and Van Horn Policy Implementation with the reason that the variables described in the theory are in accordance with the research theme that the author examines. In researching a policy, the author needs to examine what are the Standards and Targets in the policies that have been implemented, whether Human Resources (HR) are sufficient in implementing the policy, whether there is Inter-Organizational Communication in the implementation of the policy. What is the attitude of the implementing agents in their performance of implementing the policy, then whether the Social, Economic \& Political Conditions can support the successful implementation of the policy and how is the Implementor's Disposition in committing to implement the policies that have been made.

From the conceptual framework that has been explained, the author puts it in the Research Model chart, where this chart is a simple flow that describes the pattern of the relationship between the variables contained in the main theory of the research used. This simple flow is in the form of an image or flow chart which the author describes as follows: 


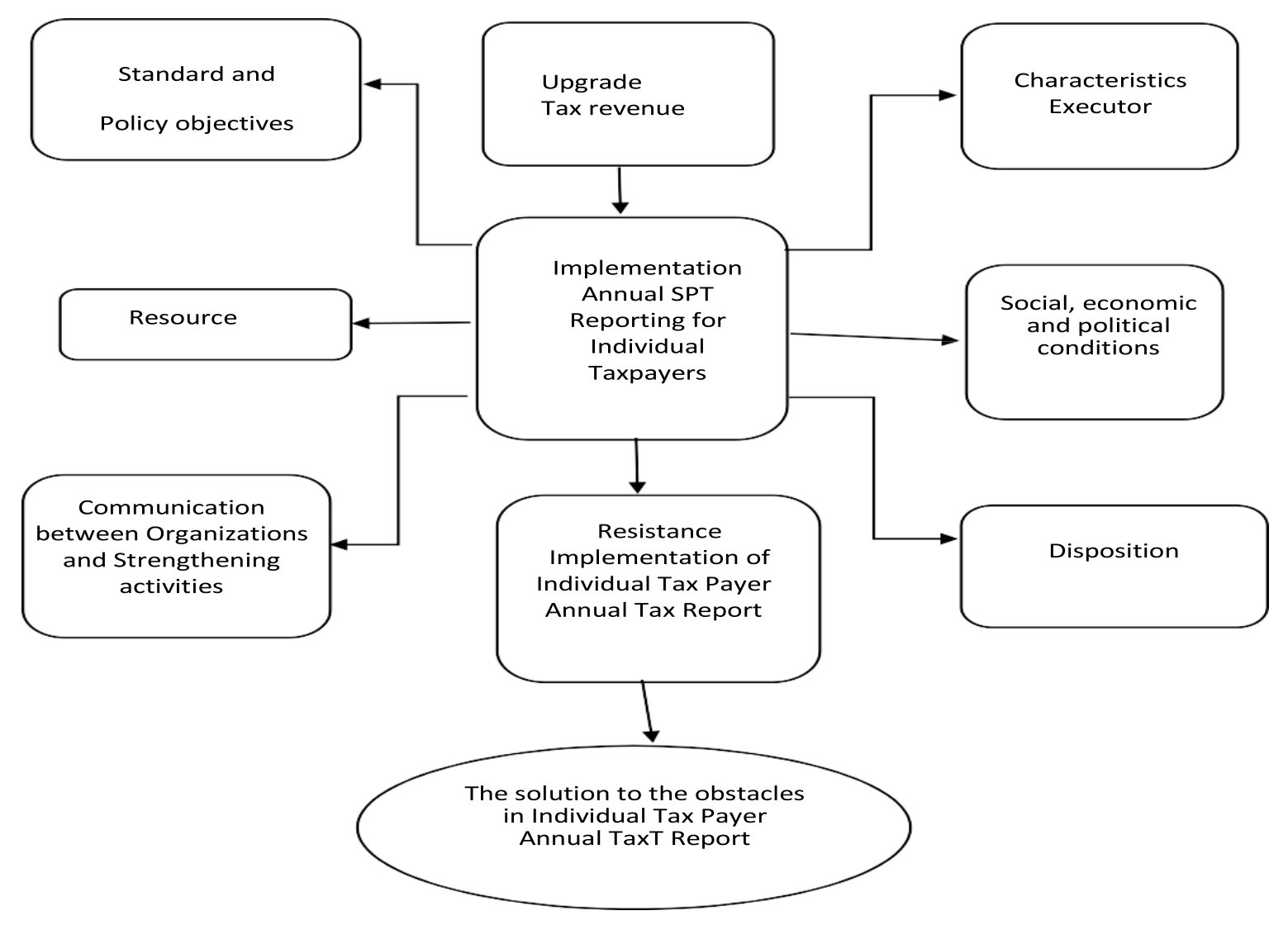

Figure 1

Conceptual Model

\section{RESULT AND DISCUSSION}

In conducting the analysis the author refers to the theory of policy implementation Donald S. Van Meter and Carl E. Van Horn which has 5 variables, namely Standards and Targets of Policy Implementation, Inter-Organizational Communication, Characteristics of Implementing Agents, Social, Political and Economic Conditions and Implementator Disposition with the results discussion as follows:

1. Standards and targets for policies implemented in the Implementation of the Annual Tax Reporting Policy for Individual Taxpayers at KPP Pratama Cileungsi.

a. From the analysis carried out by Verbatim, which was based on interviews with informants, it appears that the Standards and Targets for Implementation of the Policy for Reporting Annual Tax Returns for Individual Taxpayers are in line with the Regulation of the Minister of Finance. It is the reference number 9/PMK.03/2018 that taxpayers should use when submitting their Annual Tax Letters in order to prevent having them returned. The result concluded that KPP Pratama Cileungsi has a sufficient 
number of human resources to help taxpayers in completing and filing their annual income tax forms.

b. The outcome of the Inter-Organizational Communication variable in the Implementation of Individual Taxpayer Annual Tax Reporting Policies at KPP Pratama Cileungsi demonstrates that communication between organisations is a reference for the successful implementation of Annual SPT reporting policies, particularly communication between DGT and KPP, KPP and companies, because communication can direct taxpayers to report their annual tax returns in accordance with the provisions. For example, the DGT instructs taxpayers to report electronically so that they do not have to visit the Tax Office.

c. The findings on the Variable Characteristics of Implementing Agents in the Implementation of the Policy for Reporting Annual Tax Returns for Individual Taxpayers at KPP Pratama Cileungsi revealed that implementing agents' attitudes in implementing the Annual SPT reporting policy are in accordance with SOPs and applicable laws and regulations, namely through online efilling with the procedure mechanism contained in the Minister of Finance of the Republic of Indonesia No.9/PMK.03/2018

d. The result of Social, Political, and Economic Conditions in the Implementation of the Policy for Reporting Annual Tax Returns for Individual Taxpayers at KPP Pratama Cileungsi revealed that social, economic, and political conditions have a significant impact on the success of Annual Taxpayer SPT Reporting Individuals, particularly issues circulating in the community, which can influence taxpayers to report or not report their SPT. However, many taxpayers are still confused about how to file SPT via electronic filing.

e. The Disposition of the Implementator of the Reporting Policy of the Annual Tax Return of the Individual Taxpayer at KPP Pratama Cileungsi demonstrated that the disposition of the implementer was carried out according to the direction and commitment with the support of competent policy implementers and has the capacity to perform services without discriminating against taxpayers.

2. Obstacles faced by KPP Pratama Cileungsi in the Implementation of the Policy for Reporting Annual Tax Returns for Individual Taxpayers at KPP Pratama Cileungsi.

The findings revealed that the obstacles encountered in the implementation of the Policy for Reporting Annual Tax Returns for Individual Taxpayers at KPP Pratama Cileungsi included server errors, problems with the DJP Online system, a high volume of SPT reporting that causes the server to overload, difficulties in filling out SPT, a lack of completeness of attachments, a poor internet network, and a lack of understanding by taxpayers about whether they should submit SPT every year or not.

3. Efforts made by KPP Pratama Cileungsi if there are obstacles in the Implementation of the Reporting Policy on Annual Tax Returns for Individual Taxpayers at KPP Pratama Cileungsi.

In order to deal with the obstacles to the implementation of the Policy for Reporting Annual Tax Returns for Individual Taxpayers, KPP Pratama Cileungsi made improvements 
Analysis of the Implementation of Annual Tax Reporting Policy among Personal Tax Payer in Indonesia

Harjo and Salleh

to the OC (Operator Console) to find out what problems were being encountered, can also do socialisation and pick up the ball and appeal to taxpayers to submit their SPT, and finally by increasing the number of existing human resource.

\section{CONCLUSION}

Based on the research and analysis that has been done by the author regarding the Analysis of the Implementation of Reporting Annual Tax Returns for Individual Taxpayers at KPP Pratama Cileungsi, the authors draw conclusions including:

1. Implementation of Reporting Annual Tax Returns for Individual Taxpayers at KPP Pratama Cileungsi from 2018 to 2020 has been good and in accordance with applicable laws and regulations but has not reached the set target

2. Obstacles experienced by KPP Pratama Cileungsi in the Implementation of Reporting Annual Tax Returns for Individual Taxpayers including server errors, problems with the DJP Online system, high intensity of SPT reporting which causes server overload, difficulties in filling out SPT, lack of complete attachments, internet network, and the lack of understanding of taxpayers to submit SPT.

3. Efforts made by KPP Pratama Cileungsi to overcome obstacles include making improvements to the OC (Operator Console), conducting socialization and picking up the ball in giving an appeal to taxpayers to submit their SPT, even though in serving a decrease in income during this Covid-19 Pandemic Period, as well as by add existing HR

\section{REFERENCE}

Adi, I. K. Y. (2020). Efektifitas E-Filing Terhadap Peningkatan Kepatuhan Wajib Pajak Orang Pribadi dengan Tingkat Keamanan dan Kerahasiaan Sebagai Variabel Moderasi (Studi Empiris Pada Kantor Pelayanan Pajak Pratama Badung Utara). Journal of Applied Management and Accounting Science, 2(1), 53-66. https://doi.org/10.51713/jamas.v2i1.26

Batrancea, L., Nichita, A., Olsen, J., Kogler, C., Kirchler, E., Hoelzl, E., Weiss, A., Torgler, B., Fooken, J., Fuller, J., Schaffner, M., Banuri, S., Hassanein, M., Alarcón-García, G., Aldemir, C., Apostol, O., Bank Weinberg, D., Batrancea, I., Belianin, A., ... Zukauskas, S. (2019). Trust and power as determinants of tax compliance across 44 nations. Journal of Economic Psychology, 74, 102191. https://doi.org/10.1016/j.joep.2019.102191

Ciptaningsih, T. (2013). Determinan Kesuksesan Implementasi Aplikasi E-Faktur Pajak. Journal of Accounting Faculty of Economics, Universitas Sarjanawiyata Tamansiswa, 1(1), 52-58.

https://jurnalfe.ustjogja.ac.id/index.php/akuntansi/article/view/8

Diana, A., \& Setiawati, L. (2017). Perpajakan Indonesia Konsep, Aplikasi, dan Penuntun Praktis (1st ed.). Andi Publishing. https://library.unismuh.ac.id/opac/detail-opac?id=103035

Direktorat Jenderal Pajak. (2013). Undang-Undang KUP dan Peraturan Pelaksanaannya (K. Petrus (ed.); I). Direktorat Jenderal Pajak. https://kemenkeu.go.id/sites/default/files/uu-kup mobile.pdf 
Analysis of the Implementation of Annual Tax Reporting Policy among Personal Tax Payer in Indonesia

Harjo and Salleh

Direktorat Jenderal Pajak. (2020). Laporan Tabunan Direktorat Jenderal Pajak Tabun 2020. https://pajak.go.id/id/laporan-tahunan-2020

Ernita, K., \& Sudjiman, P. E. (2021). Pengaruh Penggunaan E-Tax Terhadap Kepatuhan Wajib Pajak (Studi pada Kantor Pelayanan Pajak Pratama Cibitung). Jurnal Ekonomi Dan Bisnis EKONOMIS, 14(1), 3-18. https://jurnal.unai.edu/index.php/jeko/article/view/2499

Handoyo, E. (2012). Kebijakan Publik (1st ed.). Widya Karya. https://staff.unnes.ac.id/dosen/eko-handoyo.html/

Harjo, D. (2019). Perpajakan Indonesia Sebagai Materi Perkuliahan di Perguruan Tinggi (D. Harjo (ed.); I). Mitra Wacana Media. https://www.mitrawacanamedia.com/perpajakan-indonesiasebagai-materi-perkuliahan-di-perguruan-tinggi-dwikora-edisi-2

Herawati, H., Tabroni, R., \& Lusiana, S. (2018). The Effectiveness of The Tax Regulation Socialization Strategies on Tax Payers' Comprehension and Compliance in Implementing Their Tax Obligations. The International Journal of Business Review (The Jobs Review), 1(2), 145154. https://doi.org/10.17509/tjr.v1i2.12980

Hidayat, T., \& Afiyanti, P. E. (2019). Pengaruh Penerapan E-SPT dan Pengetahuan Perpajakan Terhadap Kepatuhan Wajib Pajak. Jurnal Akuntansi Bisnis Pelita Bangsa, 4(1), 55-70. https://journal.lppmpelitabangsa.id/index.php/akubis/article/view/101

Janika, Pangestoeti, W., \& Kurnianingsih, F. (2019). Analisis implementasi kebijakan pajak tentang Surat Pemberitabuan elektronik (E-spt) tabunan di Kantor Pelayanan Pajak Pratama Bintan [Universitas Maritim Raja Ali Haji]. http://repositori.umrah.ac.id/id/eprint/248

Kumala, R., \& Junaidi, A. (2019). Pengaruh Kesadaran Membayar Pajak, Pengetahuan Dan Pemahaman Peraturan Perpajakan Dan Kualitas Layanan Terhadap Kemauan Membayar Pajak Wajib Pajak Orang Pribadi. Jurnal Eksekutif, 16(2), 256-278. https://jurnal.ibmt.ac.id/index.php/jeksekutif/article/view/235

Latofah, N., \& Harjo, D. (2020). Analisis Tax Awareness Dalam Upaya Meningkatkan Kepatuhan Wajib Pajak di Kantor Pelayanan Pajak Pratama Bekasi Barat. Jurnal Pajak Vokasi (JUPASI), 2(1), 52-62. https://doi.org/10.31334/jupasi.v2i1.1121

Melando, N., \& Waluyo, W. (2013). Pengaruh Pelayanan Fiskus, Persepsi Atas Efektivitas Sistem Perpajakan, Pengetahuan Pajak, Dan Kesadaran Wajib Pajak Terhadap Kepatuhan Wajib Pajak Orang Pribadi. Jurnal ULTIMA Accounting, 5(2), 17-37. https://doi.org/10.31937/akuntansi.v5i2.150

Moleong, L. J. (2018). Metodologi Penelitian Kualitatif (38th ed.). Remaja Rosdakarya. https:/ /opac.perpusnas.go.id/DetailOpac.aspx?id=1133305

Norzhela, B., Rauf, S. A., \& Hermawansyah, A. (2019). Analisis Efektivitas Kepuasan Wajib Pajak Dalam Pengisian Laporan SPT DJP Online. J-Sim : Jurnal Sistem Informasi, 2(2), 55-59. http://ojs.stmik-borneo.ac.id/index.php/J-SIm/article/view/50

Pasolong, H. (2019). Teori Administrasi Publike (9th ed.). Alfabeta. https://cvalfabeta.com/product/teori-administrasi-publik/

Perdana, E. S., \& Dwirandra, A. A. N. . (2020). Pengaruh Kesadaran Wajib Pajak, Pengetahuan Perpajakan, dan Sanksi Perpajakan Pada Kepatuhan Wajib Pajak UMKM. E-Jurnal Akuntansi, 30(6), 1458. https://doi.org/10.24843/EJA.2020.v30.i06.p09

Pohan, C. A. (2017). Pembahasan Komprehensif Pengantar Perpajakan Teori Dan Konsep Hukum Pajak 
Analysis of the Implementation of Annual Tax Reporting Policy among Personal Tax Payer in Indonesia

Harjo and Salleh

(2nd ed.). Mitra Wacana Media. https://www.mitrawacanamedia.com/pembahasankomprehensif-pengantar-perpajakan-teori-dan-konsep-hukum-pajak-edisi-2

Puspitarini, A. (2016). Implementasi Sistem E-Filing SPT Tahunan PPH Orang Pribadj Pada KPP Pratama Surabaya Pabean Cantikan [STIESIA Surabaya]. https://repository.stiesia.ac.id/id/eprint/3079/

Rahmadani, S. E., \& Munawaroh. (2017). Antisipasi Restitusi Pajak Pertambahan Nilai Atas Kegiatan Ekspor Dan Impor Pada PT YKK Zipco Indonesia. Jurnal Akuntansi Dan Bisnis Krisnadwipayana, 4(2), 34-50. https://ojs.ekonomiunkris.ac.id/index.php/JABK/article/view/120

Rahman, A., Kurniawan, I., \& Elwa, M. (2015). Panduan Pelaksanaan Administrasi Perpajakan untuk Karyawan, Pelaku Bisnis dan Perusahaan (2nd ed.). Nuansa Cendikia. https:/ / opac.perpusnas.go.id/DetailOpac.aspx?id=814576

Rusli, Y. M. (2019). Pengaruh Efektivitas Penerapan E-filling dan Modernisasi Sistem Perpajakan Indonesia Terhadap Efektivitas Pemrosesan Data Perpajakan. Jurnal Akuntansi Bisnis, 12(1). https://doi.org/10.30813/jab.v12i1.1509

Setiowati, Y. D., Fauzi, A., \& Sumiati, A. (2020). Pengaruh Kepatuhan Wajib Pajak Perusahaan dan Audit Pajak Terhadap Pendapatan Pajak Penghasilan Perusahaan : Studi Kasus di Kantor Pelayanan Pajak Jakarta Kebayoran Lama. Jurnal Bisnis Manajemen Dan Kenangan, 1(2), 407-415. http://pub.unj.ac.id/index.php/jbmk/article/view/114/133

Sinuhaji, A. A. (2019). Pengaruh Pengetahuan Pajak, Pelayanan Fiskus, Sosialisasi Dan Sanksi Pajak Terhadap Kepatuhan W ajib Pajak Orang Pribadi (Studi Kasus Di KPP Pratama Serpong [Indonesia Banking School]. http://repository.ibs.ac.id/125/

Subarsono, A. G. (2019). Analisis Kebijakan Publik (1st ed.). Pustaka Pelajar. https://pustakapelajar.co.id/buku/analisis-kebijakan-publik/

Sugiyono. (2019). Metode Penelitian Kuantitatif Kualitatif dan R\&D (I). Alfabeta. https://cvalfabeta.com/product/metode-penelitian-kuantitatif-kualitatif-dan-rd-mpkk/

Supriatiningsih, \& Jamil, F. S. (2021). Pengaruh Kebijakan E-Filing, Sanksi Perpajakan dan Kesadaran Wajib Pajak Terhadap Kepatuhan Wajib Pajak Orang Pribadi. Jurnal Ilmiah Akuntansi Kesatuan, 9(1), 191-200. https://doi.org/10.37641/jiakes.v9i1.560

Widiastuti. (2017). Pengaruh Kualitas Pelayanan Terhadap Kepatuhan Wajib Pajak Orang Pribadi dengan Kepuasan Sebagai Variabel Intervening Kantor Pelayanan Pajak Pratama Cibitung. Jurnal Akuntansi Bisnis Pelita Bangsa, 02(01), 1-15. https://journal.lppmpelitabangsa.id/index.php/akubis/article/view/110

Wulandari, D. S. (2021). Digitalisasi Sistem Administrasi Perpajakan dan Biaya Kepatuhan Pajak Terhadap Kepatuhan Wajib Pajak Orang Pribadi. Journal of Accounting Science, 5(1), 36-70. https://jas.umsida.ac.id/index.php/jas/article/view/1131 